\title{
INDUCED OVULATION IN MATURE MICE AND DEVELOPMENTAL CAPACITY OF THE EMBRYOS IN VITRO
}

\author{
AKIKO I. SPINDLE AND L. S. GOLDSTEIN \\ Laboratory of Radiobiology, University of California, \\ San Francisco, California 94143, U.S.A.
}

(Received 13th November 1974)

\begin{abstract}
Summary. Embryos from gonadotrophin-treated mature mice were cultured from the two-cell to the early implantation stage. Their developmental capacity was very similar to that of spontaneously ovulated eggs.
\end{abstract}

Although embryos obtained after superovulation from mature mice are used extensively for studies in vitro and various assays in many laboratories, no attempt has been made to compare their developmental capacity in vitro beyond the blastocyst stage with that of fertilized eggs obtained after natural ovulation. In the experiment reported here, embryos from gonadotrophintreated mature mice were cultured from the two-cell to early implantation stage and their developmental capacity was compared with that of embryos which were similarly cultured after natural ovulation. The in-vitro system used was sensitive enough to investigate genetic abnormalities (Pedersen, 1974) and effects of preimplantation X-irradiation (Goldstein, Spindle \& Pedersen, 1975) manifested during late preimplantation and early implantation stages.

Female mice of the IGR strain (6 weeks old, Flow Laboratories) were maintained on a 14-hr light schedule (from 06.00 to 20.00 hours) for at least 1 week after their arrival. Males of the ICR strain (6 to 7 months old, Flow Laboratories) were caged individually and randomized by the use of a random permutation table (Fisher \& Yates, 1957) before each experiment. The females were allocated randomly to ten experimental groups and the mice in Groups 1 to 9 were injected first with PMSG (Sigma) between 15.00 and 17.00 hours and then with HCG (Ayerst) 45 to $47 \mathrm{hr}$ later. The hormones were dissolved in $0.9 \%$ saline and injected intraperitoneally in a volume of $0.1 \mathrm{ml}$. The doses tested were $1 \cdot 25,2 \cdot 5$, and 5 i.u. for each hormone in their nine combinations. Immediately after injection of $\mathrm{HCG}$, two females were caged with each male and successful mating was noted by the presence of copulatory plugs the next morning (Day 1 of pregnancy).

Pregnant females were killed on Day 2 (between 09.00 and 12.00 hours) by cervical dislocation. The embryos were flushed from the oviducts with modified Hanks' balanced salt solution (BSS; Leibovitz, 1963) containing $1.71 \mathrm{~mm}$-calcium lactate, $0.25 \mathrm{~mm}$-sodium pyruvate, 100 i.u. penicillin $/ \mathrm{ml}$, 
$50 \mu \mathrm{g}$ streptomycin $/ \mathrm{ml}, 3 \mathrm{mg}$ bovine serum albumin (Pentex) $/ \mathrm{ml}$, and reduced $\mathrm{NaCl}$ (129 mM). Two-cell embryos from each female were counted and the embryos from each group were pooled and cultured in an organ culture dish (Falcon Plastics) containing $0.8 \mathrm{ml}$ standard egg culture medium (Biggers, Whitten \& Whittingham, 1971) with reduced $\mathrm{NaCl}(84 \mathrm{~mm})$ and $\mathrm{NaHCO}_{3}$ $(22.5 \mathrm{~mm})$. The embryos were incubated at $37^{\circ} \mathrm{C}$ in an humidified atmosphere of $5 \% \mathrm{CO}_{2}$ in air.

The embryos were examined for blastulation under a dissecting microscope 3 days ( 72 to $74 \mathrm{hr}$ ) later. All blastocysts were then transferred to eight-chamber culture slides (Lab-Tek, fifteen embryos/chamber) containing Eagle's basal medium (BME; Eagle, 1955) with reduced NACl (102 mM), optimal concentrations of essential amino acids (Spindle \& Pedersen, 1973), 5\% fetal bovine serum, and $5 \%$ newborn calf serum (both from GIBCO). After 5 days in modified BME, the embryos were examined under a dissecting microscope for formation of trophoblast outgrowth, the presence of an inner cell mass, and its differentiation into endoderm and ectoderm.

The \% of two-cell embryos developing to the blastocyst stage and of blastocysts growing further to each endpoint did not vary significantly from replicate to replicate $(P>0.05)$, so the results of the four replicate experiments were pooled. Difference in response between groups was tested by Student's $t$ test of significance.

The number of females mating after treatment with gonadotrophins was significantly higher $(57 \%)$ than for untreated females $(19 \%)$. The doses and the different combinations of the two hormones had little effect on mating efficiency, except for the mice in Groups 8 and 9, which showed significantly lower over-all mating efficiency $(P<0.05$, Table 1$)$. Even in these groups, however, the $\%$ of mating was as high as 62.5 in some experiments. A similar variation between replicates was also observed for the mice in Group 7 and to a lesser degree for the mice in all other groups, indicating that occurrence of mating was largely dependent on individual animals.

After superovulation, females from Groups 1 to 4 yielded significantly $(P<0.05)$ higher numbers of two-cell embryos than did spontaneously ovulating mice (Group 10, Table 1). The highest number of embryos/mouse was consistently obtained from Group-1 females, which had received 5 i.u. of both hormones. Both PMSG and HCG influenced the yield of embryos, although the effect of PMSG was much greater. When the level of HCG was held constant and the PMSG levels were varied, the number of embryos increased with the PMSG level. Treatment with HGG influenced embryo yields only when the PMSG level was sub-optimal (1.25 i.u.), in which case the number of embryos correlated positively with the level of HCG.

By contrast, neither blastulation nor any of the later events was affected by the level of hormones administered (Table 2). Approximately $85 \%$ of the embryos from the hormone-treated mice and $83 \%$ of the embryos from the untreated mice reached the blastocyst stage after 72 to $74 \mathrm{hr}$ in culture. All denuded embryos attached and formed trophoblast outgrowths. Only $2.5 \%$ of blastocysts formed trophoblast outgrowths without shedding the zona pellucida completely. The $\%$ of blastocyts that formed trophoblast outgrowths with 
clearly recognizable inner cell masses were 84.0 and 80.1 for the mice in Groups 1 to 9 and in control Group 10, respectively. About half of these embryos were well developed egg cylinders with two layers- $52.7 \%$ for the treated mice and $44.2 \%$ for the control mice.

Since the females given 5 i.u. of both PMSG and HGG (Group 1) yielded the highest number of embryos and the developmental capacity of the embryos was comparable to that of spontaneously ovulating embryos, three replicate

Table 1. Mating efficiency of mice and embryo yield at various hormone levels

\begin{tabular}{|c|c|c|c|c|}
\hline $\begin{array}{c}\text { Experimental } \\
\text { group }\end{array}$ & $\begin{array}{c}P M S G \\
(\text { i.u. })\end{array}$ & $\begin{array}{l}H C G \\
(i . u .)\end{array}$ & $\begin{array}{c}\text { No. of mice } \\
\text { mated }\end{array}$ & $\begin{array}{l}\text { No. of two-cell } \\
\text { embryos/mouse } \\
\text { (Mean } \pm \text { S.E.) }\end{array}$ \\
\hline $\begin{array}{r}1 \\
2 \\
3 \\
4 \\
5 \\
6 \\
7 \\
8 \\
9 \\
10\end{array}$ & $\begin{array}{l}5 \\
5 \\
5 \\
2 \cdot 5 \\
2 \cdot 5 \\
2 \cdot 5 \\
1 \cdot 25 \\
1.25 \\
1.25 \\
0\end{array}$ & $\begin{array}{l}5 \\
2 \cdot 5 \\
1 \cdot 25 \\
5 \\
2 \cdot 5 \\
1 \cdot 25 \\
5 \\
2 \cdot 5 \\
1 \cdot 25 \\
0\end{array}$ & $\begin{array}{l}21 / 32 \\
17 / 32 \\
19 / 32 \\
22 / 32 \\
23 / 32 \\
21 / 32 \\
17 / 32 \\
12 / 32 \\
13 / 32 \\
19 / 100\end{array}$ & $\begin{array}{r}29 \cdot 8 \pm 3 \cdot 3 \\
19.5 \pm 2 \cdot 1 \\
23.4 \pm 3 \cdot 5 \\
19 \cdot 0 \pm 2 \cdot 8 \\
12 \cdot 2 \pm 1 \cdot 5 \\
15 \cdot 1 \pm 1 \cdot 7 \\
14 \cdot 6 \pm 2 \cdot 5 \\
11 \cdot 3 \pm 1 \cdot 3 \\
8 \cdot 3 \pm 0.9 \\
9 \cdot 9 \pm 1 \cdot 0\end{array}$ \\
\hline
\end{tabular}

Table 2. Development of mouse embryos in vitro after induced and natural ovulation

\begin{tabular}{rccccc}
\hline & & \multicolumn{3}{c}{ No. of embryos with: } \\
\cline { 3 - 6 } $\begin{array}{c}\text { Experimental } \\
\text { group }\end{array}$ & $\begin{array}{c}\text { No. of two-cell } \\
\text { embryos }\end{array}$ & $\begin{array}{c}\text { No. of blastocysts } \\
(\%)^{*}\end{array}$ & $\begin{array}{c}\text { Trophoblast } \\
\text { outgrowths } \\
(\%) \dagger\end{array}$ & $\begin{array}{c}\text { Inner cell } \\
\text { mass } \\
(\%) \dagger\end{array}$ & $\begin{array}{c}\text { Two germ-cell } \\
\text { layers } \\
(\%) \dagger\end{array}$ \\
\hline 1 & 628 & $497(79 \cdot 1)$ & $471(94 \cdot 8)$ & $425(85 \cdot 7)$ & $218(43 \cdot 9)$ \\
2 & 292 & $263(90 \cdot 1)$ & $244(92 \cdot 8)$ & $195(74 \cdot 5)$ & $114(43 \cdot 3)$ \\
3 & 433 & $358(82 \cdot 7)$ & $323(90 \cdot 2)$ & $251(78 \cdot 1)$ & $112(31 \cdot 7)$ \\
4 & 412 & $351(85 \cdot 2)$ & $323(92 \cdot 0)$ & $293(83 \cdot 5)$ & $154(43 \cdot 9)$ \\
5 & 281 & $232(82 \cdot 6)$ & $218(94.0)$ & $179(77 \cdot 2)$ & $78(33 \cdot 6)$ \\
6 & 315 & $256(81 \cdot 3)$ & $246(96 \cdot 1)$ & $212(82 \cdot 8)$ & $120(46 \cdot 9)$ \\
7 & 249 & $224(90 \cdot 0)$ & $214(95 \cdot 5)$ & $170(75 \cdot 9)$ & $68(30 \cdot 4)$ \\
8 & 132 & $125(94 \cdot 7)$ & $118(94 \cdot 4)$ & $90(72 \cdot 0$ & $40(32 \cdot 0)$ \\
9 & 107 & $100(93 \cdot 5)$ & $85(85 \cdot 0)$ & $68(68 \cdot 0)$ & $30(30 \cdot 0)$ \\
10 & 188 & $156(83 \cdot 0)$ & $151(96 \cdot 7)$ & $121(76 \cdot 1)$ & $59(37 \cdot 8)$ \\
\hline
\end{tabular}

*\% of two-cell embryos.

experiments involving a total of 108 females were performed using 5, 7.5 and 10 i.u. PMSG and HCG in their nine combinations. The results (data not shown) indicated that there was no advantage from using higher levels of the hormones. Neither the number of embryos/mouse nor the \% of embryos developing to each endpoint differed significantly among the nine groups.

The number of embryos/mouse after different hormone doses in this study was very similar to that reported by Fowler \& Edwards (1957) for several strains (N, C, J, C57, and L) of mice. Our results also agree with the finding of Wilson \& Zarrow (1962) in immature mice (Purdue-Swiss strain) that the 
number of embryos/mouse increases with the PMSG dose up to 5 i.u. and remains relatively constant between 5 and 10 i.u. Our finding that, with a suboptimal level of PMSG, the number of embryos/mouse varied with the level of HCG administered agrees with the results of Wilson \& Zarrow (1962), although Fowler \& Edwards reported (1957) that various amounts of HCG in their experiments did not influence the number of eggs ovulated. In addition, our finding that the rate of preimplantation development of embryos after induced ovulation was very similar to that of embryos obtained from mice after spontaneous ovulation agrees with the in-vivo finding reported by Allen \& McLaren (1971). Similarly, the \% of embryos from induced ovulation that developed to the blastocyst stage in our experiment (84.5) closely approximates the value $(82 \cdot 7)$ reported by Gates (1965).

Since none of the events following the blastocyst stage was affected by whether ovulation was induced or natural or by the amount of hormones given, the failure to implant reported by Fowler \& Edwards (1957) for embryos obtained after superovulation does not appear to be due to defects in the embryos but to maternal factors, as was suggested by the authors. Possibilities of failure in development beyond our culture period, however, cannot be excluded. Fujimoto, Pahlavan \& Dukelow (1974) recently found chromosomal abnormalities in rabbit embryos obtained after superovulation, so it is possible either that any chromosomal abnormalities caused by gonadotrophin treatment are not expressed during our culture period or that the hormone levels used in our study were too low to cause a sufficiently high incidence of chromosomal abnormalities to be detected in our in-vitro system.

The work was performed under the auspices of the U.S. Atomic Energy Commission.

\section{REFERENGES}

Allen, J. \& MaLaren, A. (1971) Cleavage rate of mouse eggs from induced and spontaneous ovulation. J. Reprod. Fert. 27, 137-140.

Biggers, J. D., Whitten, W. K. \& Whittingham, D. G. (1971) The culture of mouse embryos in vitro. In Methods in Mammalian Embryology, pp. 86-116. Ed. J. C. Daniel, Jr. Freeman, San Francisco.

EAGLE, H. (1955) Nutrition needs of mammalian cells in tissue culture. Science, N.Y. 122, 501-504.

Fisher R. A. \& Yates, F. (1957) Statistical Tables for Biological, Agricultural and Medical Research, 5th edn, p. 69. Harper, New York.

FowLER, R. E. \& EDWARDS, R. G. (1957) Induction of superovulation and pregnancy in mature mice by gonadotrophins. F. Endocr. 15, 374-384.

Fujimoto, S., Pahlavan, N. \& Dukelow, W. R. (1974) Chromosome abnormalities in rabbit preimplantation blastocysts induced by superovulation. F. Reprod. Fert. 40, 117-181.

Gates, A. H. (1965) Rate of ovular development as a factor in embryonic survival. In Ciba Fndn Symp.: Preimplantation Stages of Pregnancy, pp. 270-288. Eds. G. E. W. Wolstenholme and M. O'Connor. Churchill, London.

Goldstein, L. S., Spindle, A. I. \& Pedersen, R. A. (1975) X-ray sensitivity of the preimplantation mouse embryo in vitro. Radiat. Res. (in press).

Leibovitz, A. (1963) The growth and maintenance of tissue-cell cultures in free gas exchange with the atmosphere. Am. F. Hyg. 78, 173-180.

Pedersen, R. A. (1974) Development of lethal yellow ( $\left.\mathrm{A}^{y} / \mathrm{A}^{y}\right)$ mouse embryos in vitro. F. exp. Zool. $188,307-319$.

Spindle, A. I. \& Pedersen, R. A. (1973) Hatching, attachment, and outgrowth of mouse blastocysts in vitro: fixed nitrogen requirements. F. exp. Zool. 186, 305-318.

Wilson, E. D. \& ZARRow, M. X. (1962) Comparison of superovulation in the immature mouse and rat. J. Reprod. Fert. 3, 148-158. 